\section{Implementation of Sensor-based Automated Irrigation in Commercial Floriculture Production: A Case Study}

\author{
William D. Wheeler, Paul Thomas, Marc van Iersel, \\ and Matthew Chappell ${ }^{1}$
}

AdDITIONAL INDEX wORDs. poinsettia, Euphorbia $\times$ pulcherrima, geranium, Pelargonium $\times$ bortorum, extension, outreach, wireless networks

SUMMARY. A soil moisture sensor-based automated irrigation system was trialed in a commercial floriculture greenhouse to determine what benefits these types of systems may offer to herbaceous ornamental producers. Water use, crop quality and growth, and grower behavior toward adoption of the new technology were monitored, when all decision making related to system operation was carried out by the grower. Two cultivars of poinsettia (Euphorbia $\times$ pulcherrima) and three cultivars of geranium (Pelargonium $\times$ bortorum) were produced in side-by-side trials over the course of 2 years while comparing grower-controlled, sensor-based automated irrigation with traditional grower-managed (timer-based) irrigation. Plant quality was equivalent between irrigation treatments across all five trials. Differences in plant size were noted in four of the five trials between irrigation treatments, but in all instances these differences were not judged by the commercial grower to impact marketability of the crop. No reductions in irrigation water use were noted with the sensor-based irrigation system, which differed from previous research using this technology in ornamental production. Over the course of 2 years, the number of plants produced using sensor-based irrigation control was scaled up, indicating increasing confidence in, and adoption of, the technology. Managers at the facility found that sensor-based irrigation facilitated reallocation of labor from irrigation management, which was especially valuable during peak production and shipping periods. The payback period calculated from labor savings would be roughly 1.5 years if the sensor-based irrigation system was implemented throughout the facility.

A gricultural water scarcity resulting from climate change, a growing population, and increased environmental regulation is expected to become more pervasive in the future (Strzepek and Boehlert, 2010). Water scarcity has the potential to significantly impact floriculture production in some, if not all, regions of the United States, which is valued at $\approx \$ 4$ billion annually [U.S. Department of Agriculture (USDA), 2015a]. State and federal regulations that limit water consumption and runoff for floricultural and specialty crop production are already in place in

Department of Horticulture, University of Georgia, 1111 Miller Plant Science Building, Athens, GA 30602

We thank Michael and Lisa Davis, owners of Davis Floral Company (Dewey Rose, GA), and their staff for their participation in this study. Funding for this project was made possible by a USDA-NIFA Specialty Crop Block Grant administered by the Georgia Department of Agriculture.

This paper is a portion of a thesis submitted by the first author in fulfilling an M.S. degree requirement.

${ }^{1}$ Corresponding author. E-mail: hortprod@uga.edu.

https://doi.org/10.21273/HORTTECH04114-18 some areas of the United States (Fulcher et al., 2016). These regulations are expected to increase in stringency and prevalence as the population increases, urban and suburban centers continue to expand, and the public's understanding of the functional value of ecosystems grows (Costanza et al., 2014). Resulting regulatory and environmental pressures will create greater incentives for floriculture producers to effectively manage limited water resources moving forward (Fereres et al., 2003), even in areas where water costs are currently low and water availability high. In addition to future water availability concerns, labor costs and employee management, retention, and training are persistent challenges for commercial horticulture producers. Mathers et al. (2010) noted that labor accounts for $40 \%$ of nursery production costs, whereas labor retention rates were $51 \%$ after 5 years. The horticulture industry is facing critical shortfalls in labor pools with tightening regulations regarding migrant workers and an increasingly competitive domestic labor market (Bellenger et al., 2008). Greenhouse and nursery positions are typically lower paying, averaging $\$ 19,330$ annually, making worker acquisition and retention difficult (Bureau of Labor Statistics, 2015; U.S. Census Bureau, 2015).

Automation and mechanization are means by which horticultural producers are overcoming labor challenges (Posadas et al., 2008). Automation has been found to have a number of benefits for specialty crop producers, including improving production quality, reducing production costs, increasing market value, reducing hazardous working conditions, and improving professional esteem (Ling, 1994). Automated irrigation through precision soil moisture sensing has been shown to be an efficient means of regulating irrigation application (Lea-Cox et al., 2013; Majsztrik et al., 2013). Although a number of different soil moisture sensors exist, capacitance sensors have been used to calculate volumetric water content $(\theta)$. These sensors have been used in commercial nursery trials in conjunction with wireless networks to produce a number of observed benefits (Belayneh et al., 2013; Chappell et al., 2013a; van Iersel et al., 2009). Significant reductions in irrigation water usage, as well as reductions in crop production times and crop shrinkage due to disease have been noted (Chappell et al., 2012). Economic analysis by Lichtenberg et al. (2013) reported that sensor-based automated irrigation systems increased annualized nursery profits by $50 \%$ over standard irrigation

\begin{tabular}{llll}
\hline $\begin{array}{l}\text { Units } \\
\text { To convert U.S. to SI, } \\
\text { multiply by }\end{array}$ & U.S. unit & SI unit & $\begin{array}{l}\text { To convert SI to U.S., } \\
\text { multiply by }\end{array}$ \\
\hline 0.3048 & $\mathrm{ft}$ & $\mathrm{m}$ & 3.2808 \\
3.7854 & $\mathrm{gal}$ & $\mathrm{L}$ & 0.2642 \\
2.54 & inch(es) & $\mathrm{cm}$ & 0.3937 \\
16.3871 & $\mathrm{inch}^{3}$ & $\mathrm{~cm}^{3}$ & 0.0610 \\
1 & ppm & $\mathrm{mg}^{3} \mathrm{~L}^{-1}$ & 1 \\
$\left({ }^{\circ} \mathrm{F}-32\right) \div 1.8$ & ${ }^{\circ} \mathrm{F}$ & ${ }^{\circ} \mathrm{C}$ & $\left({ }^{\circ} \mathrm{C} \times 1.8\right)+32$
\end{tabular}

Hortednology $\cdot$ December $201828(6)$ 
practices. Savings in labor, irrigation volume, fungicides, fertilizers, energy costs for pumping, and accelerated crop production times all contributed to making soil moisture sensor-based automated irrigation more profitable than conventional (often timer-based) methods of irrigation. Saavoss et al. (2016) had similar findings when comparing implementation of sensor-based automated irrigation in cut snapdragon (Antirrhinum majus) production. Sensor-based irrigation increased profits by $65 \%$ per year by improving quality and number of stems produced per crop, as well as reducing production time per crop, allowing an additional 2.5 crops per year to be produced. In addition, sensor-based automated irrigation systems have been used in a number of controlled studies in university greenhouses. Floriculture species trialed in these studies have included petunia [Petunia $\times$ bybrida (van Iersel et al., 2010)], poinsettia (Alem et al., 2015a), and periwinkle [Catharanthus roseus (Kim and van Iersel, 2011)]. To our knowledge there have been only three studies (Kim et al., 2014; Lea-Cox et al., 2018; Ristvey et al., 2018) looking at implementation of sensor-based irrigation in commercial production of floriculture crops. These studies have all shown extensive benefits from implementing sensor-based automated irrigation, but have had extensive input from researchers in controlling these types of systems in a commercial setting. The current study postulated that many of the benefits of soil moisturebased automated irrigation observed in nursery crop production and in university-based floriculture trials also would be observed when the system was installed and operated by a commercial floriculture producer. This study sought to determine what advantages these types of systems could offer commercial floriculture producers and observe grower behavior in relation to adoption of the new technology when the producer was allowed full system control, with no researcher input, after an initial training consultation. We hypothesized that soil moisture sensorbased automated irrigation would be readily adopted by the participating grower. In addition, we hypothesized that soil moisture sensor-based automated irrigation would reduce the volume of applied irrigation water while producing equal size and quality plants when compared with traditional timer-based irrigation management.

\section{Materials and methods}

CoMmercial PARTNer AND PLANT MATERIAL. Davis Floral Company (DFC; Dewy Rose, GA) was selected to participate in the study based on willingness to adopt new technology, education level of owners (B.S. Horticulture and M.S. Business Administration), openness to allowing research to be conducted on-site, and expressed interest in automated irrigation technology. DFC is a commercial floriculture producer that uses gutter-connected, polyethylenecovered houses and produces primarily finished annuals and cuttings for the wholesale market. Dewy Rose, GA (lat. $34^{\circ} 09^{\prime} 16.4^{\prime \prime} \mathrm{N}$, long. $\left.82^{\circ} 56^{\prime} 01.0^{\prime \prime} \mathrm{W}\right)$, is in USDA hardiness zone $8 \mathrm{~A}$. Five separate trials (e.g., production cycles) were carried out in 2014 and 2015 to compare sensor-based automated irrigation to traditional timer-based growercontrolled irrigation management. All trials took place in two bays of a greenhouse with each bay measuring $145 \mathrm{ft}$ long $\times 70 \mathrm{ft}$ wide $\times 15 \mathrm{ft}$ (maximum) height. Plants were produced within the greenhouse either on a fabriccovered gravel pad or on elevated wooden benches $(5 \mathrm{ft}$ wide $\times 65 \mathrm{ft}$ long). Species trialed included three cultivars of geranium (Fantasia Cardinal Red, Fantasia Shocking Pink, and Fantasia Salmon), and two cultivars of poinsettia (Prestige Red and Christmas Day Red). Geranium and poinsettia cultivars were grown in 8inch-diameter and 6.5-inch-diameter containers (The HC Companies, Middlefield, $\mathrm{OH}$ ), respectively. All containers were consumer-grade opaque plastic that were loosely filled with commercially available peat-perlitebased growing media (Metro-Mix 360; Sun Gro Horticulture, Agawam, MA).

IRRIGATION CONTROL AND ENVIRONMENTAL DATA. Control treatments for all trials were based on historic irrigation practices used by DFC, which included twice-daily visual inspection of the crop followed by manual irrigation initiation with a timer-based shutoff if irrigation was deemed necessary by the grower. Irrigation was applied to the control treatment via drip tape with emitters rated at $0.4 \mathrm{gal} / \mathrm{h}$ at 16 -inch spacing (Space-It; Netafim, Fresno, CA). In some cases, when the entire crop did not need to be irrigated, primarily edge plants were hand-watered using a handheld wand. For simplicity of terminology, we refer to all growerbased irrigation as timer-based irrigation, as this is the primary historic method that DFC used to irrigate crops and hand watering was infrequently practiced.

A soil moisture sensor-based automated irrigation system, similar to systems used to control irrigation in commercial nursery settings described by Chappell et al. (2013a), was used to provide irrigation to experimental treatments. Five soil moisture sensors (GS3; Decagon Devices, Pullman, WA) were distributed randomly throughout each crop and inserted with the metal prongs aligned vertically downward through the surface of the media. The sensor prongs were entirely inserted into the substrate, with the sensor head at the substrate surface. Sensors were calibrated before the start of the trial at the University of Georgia Horticulture Physiology Laboratory for a peat:perlite [80:20 by volume (Fafard lp; Fafard, Agawam, MA)] substrate $\left(\theta=-0.00045965 \times\right.$ voltage $^{2}+$ $0.036346 \times$ voltage $+0.0528, r 2=$ $0.95)$. Sensors were connected to wireless nodes (nR5-DC; Decagon Devices) and provided readings of $\theta$, bulk electrical conductivity, and soil temperature. Each wireless node was also capable of controlling a 12-V DC latching solenoid valve (075-DV three-fourths inch; Rain Bird, Azusa, CA) that regulated the flow of irrigation water. Over the course of 2 years, a total of four nodes were used to monitor and control $\theta$ for 300 to 450 plants per node. One additional node was deployed as a dedicated weather station, monitoring environmental conditions within the greenhouse. Light levels were monitored using a pyranometer (PYR; Decagon Devices) and air movement through the house was measured using a cup anemometer (Davis; Decagon Devices). Temperature and relative humidity were monitored using a temperature and humidity sensor (EHT; Decagon Devices) and cumulative irrigation volume was monitored using eight flow meters (DLJ SJ50; Daniel L. Jerman Co., Hackensack, NJ). Nodes collected readings at 60 -s intervals and transmitted the averages every $20 \mathrm{~min}$ back to a centrally located base station connected to a computer using a $900-\mathrm{MHz}$ radio (XSC; Digi, Minnetonka, MN). 
Software to provide a graphical user interface (GUI) and control the sensorbased irrigation system, developed by Carnegie Mellon University (Kohanbash et al., 2013), was installed on the computer and provided monitoring and control capabilities. The software used a web-based GUI that provided access directly at the computer station and remotely over the Internet. The GUI allowed growers to toggle computercontrolled irrigation on and off, establish irrigation set points, and view data collected by the sensor network. Growers established irrigation set points at DFC after $7 \mathrm{~d}$ of monitoring $\theta$ values. These set points were determined based on $\theta$ readings from the monitoring period, as well as visual inspection of the $\operatorname{crop}(s)$ at daily intervals. When visual observations indicated the crop had dried to a point at which the grower would typically initiate a manual (timer-based) irrigation cycle, the GUI was consulted to determine the corresponding average $\theta$, which would become the irrigation set point. When average $\theta$ readings of four sensors connected to a single node fell below the programmed set point, an irrigation event lasting $300 \mathrm{~s}$ was triggered. Because this was a protype system, the programmed irrigation interval coded into the software could not be altered. The system software was programmed to check average $\theta$ after each irrigation event and if average $\theta$ was still below the programmed set point, an additional irrigation event was triggered. There was no limit to the number of irrigation events that could occur daily. All plants were placed under drip tape with emitters rated at $0.4 \mathrm{gal} / \mathrm{h}$ at 16 inch spacing (Space-It; Netafim Inc., Fresno, CA). Fertilization for sensorbased irrigation was specific to each crop and was managed by the section grower to reflect fertilization rates of the growerirrigated (timer-control) treatment(s). Fertilization for geranium used $12 \mathrm{~N}-$ 0.9P-11.6K (Plantex Cal Mag + P; Master Plant-Prod Inc., Brampton, ON, Canada) at 200 ppm nitrogen (N). Poinsettia production used 300 ppm $\mathrm{N}$ of $20 \mathrm{~N}-8.7 \mathrm{P}-16.6 \mathrm{~K}$ (J.R. Peters, Allentown, PA) from transplant until first bract color. Once bracts had colored, fertigation was lowered to 200 ppm N of 17N-2.2P-14.1K (Plantex; Master Plant-Prod Inc.). Plants were fertilized at every irrigation event triggered by the sensor-based irrigation system using dedicated injectors (DM14Z2; Dosatron, Clearwater, FL) set to a $1: 128$ injection ratio.
Initial setup of the sensor-based irrigation system occurred on week 14 of 2014 and was used to monitor but not control irrigation in a 'Fantasia Scarlet Improved' geranium crop. This initial monitoring period allowed researchers to consult with growers on operation of the system and software, and note soil moisture profiles generated by their irrigation management practices. Irrigation was first controlled by the DFC staff starting at week 35 of 2014 in 'Prestige Red' poinsettia. Following the initial trial with poinsettia in the fall, 'Fantasia Cardinal Red', 'Fantasia Shocking Pink', and 'Fantasia Salmon' geranium were trialed in Spring 2015 staring on week 6. 'Prestige Red' poinsettia trials were scaled up and repeated in Fall 2015 starting on week 35 and 'Christmas Day Red' was added to the trial.

Data collection. Growth indexes were calculated as the product of canopy height from the soil line, width of the plant at its widest point, and width perpendicular to that point (growthindex $=$ height $\times$ width $1 \times$ width 2$)$. Plant quality was assessed on a standardized 1 to 10 scale developed in coordination with DFC staff, with 1 being a completely dead plant and 10 being a plant with vigorous growth, attractive symmetrical habit, and good foliar tone. Flow meter readings were taken at each sampling period and back-calculated to determine total water use over time. Dry weight measurements were collected from 20 randomly selected plants from each treatment by cutting shoots at the soil line at the end of each trial followed by drying at $85^{\circ} \mathrm{C}$ for $72 \mathrm{~h}$. In geranium trials, when plants were determined to be market ready by the grower, the number of inflorescences per plant (for all plants in a treatment) was counted and used to determine the average number of inflorescences per plant. When poinsettias were deemed market ready, anthocyanin content index was sampled on the bracts of 20 plants per treatment using an anthocyanin meter (ACM-200 plus; Opti-Sciences, Hudson, NH). Bract area was determined when plants were considered marketable by selecting three of the largest colored bracts per plant from 20 plants per treatment and measuring leaf area using a leaf area index meter (LI-3000C; LI-COR, Lincoln, NE).
Labor time measurements related to irrigation activities were measured over three, 14-d periods in 2015 during the poinsettia crop cycle using push-button timers (MeasuPro Fifure 8; Better Basics, Chestnut Ridge, NY) located at the irrigation controllers for both irrigation treatments as well as the base station computer used to access the GUI.

Grower interviews. At the onset of this study, DFC staff were trained on proper use of the sensorbased irrigation system while growing a 'Fantasia Scarlet Improved' geranium crop between weeks 14 and 20. Thereafter, researchers served only in a consulting role, with DFC staff controlling all system operation, and initiating all communications with researchers regarding system use and troubleshooting. Researchers intervened only once, because of system malfunction, as a node failed in Summer 2015 due to a suspected lightning strike. DFC staff were able to alter irrigation set points as they saw fit throughout a crop cycle (Fig. lA-C). Consultation with researchers also consisted of follow-up training of two newly hired staff on how to use the system and how to troubleshoot system errors, similar to the training provided to DFC owners and staff at the onset of this study. Throughout the course of the 2-year study, DFC staff behavior and opinions of the sensor-based irrigation system were documented quarterly. Semistructured interviews were conducted with the owners, head grower, and section grower to determine their impressions and document comments about the system. During these interviews, researchers did not offer suggestions or training on system use (even when the system was being used improperly), as not to influence DFC staff use of the system. Two annual presentations were given in which results from the studies conducted the previous 12 months were discussed and growers were formally asked for their input on the performance of the system.

EXPERIMENTAL DESIGN AND STATISTICS. All trials used sideby-side comparisons of sensor-based automated irrigation (with growerdefined irrigation set points) to that of traditional grower-managed (timer-based) irrigation. Irrigation treatments were treated as fixed effects when analyzing for treatment 
differences. For all trials, sample plots consisting of 125 plants were established in each irrigation treatment, from which 20 were randomly selected for evaluation of plant quality and growth indexes over the course of a crop cycle. Evaluations were performed every $14 \mathrm{~d}$ after the start of each trial, which initiated $7 \mathrm{~d}$ after planting. When deemed market ready by DFC staff, 20 plants were randomly selected for additional quality
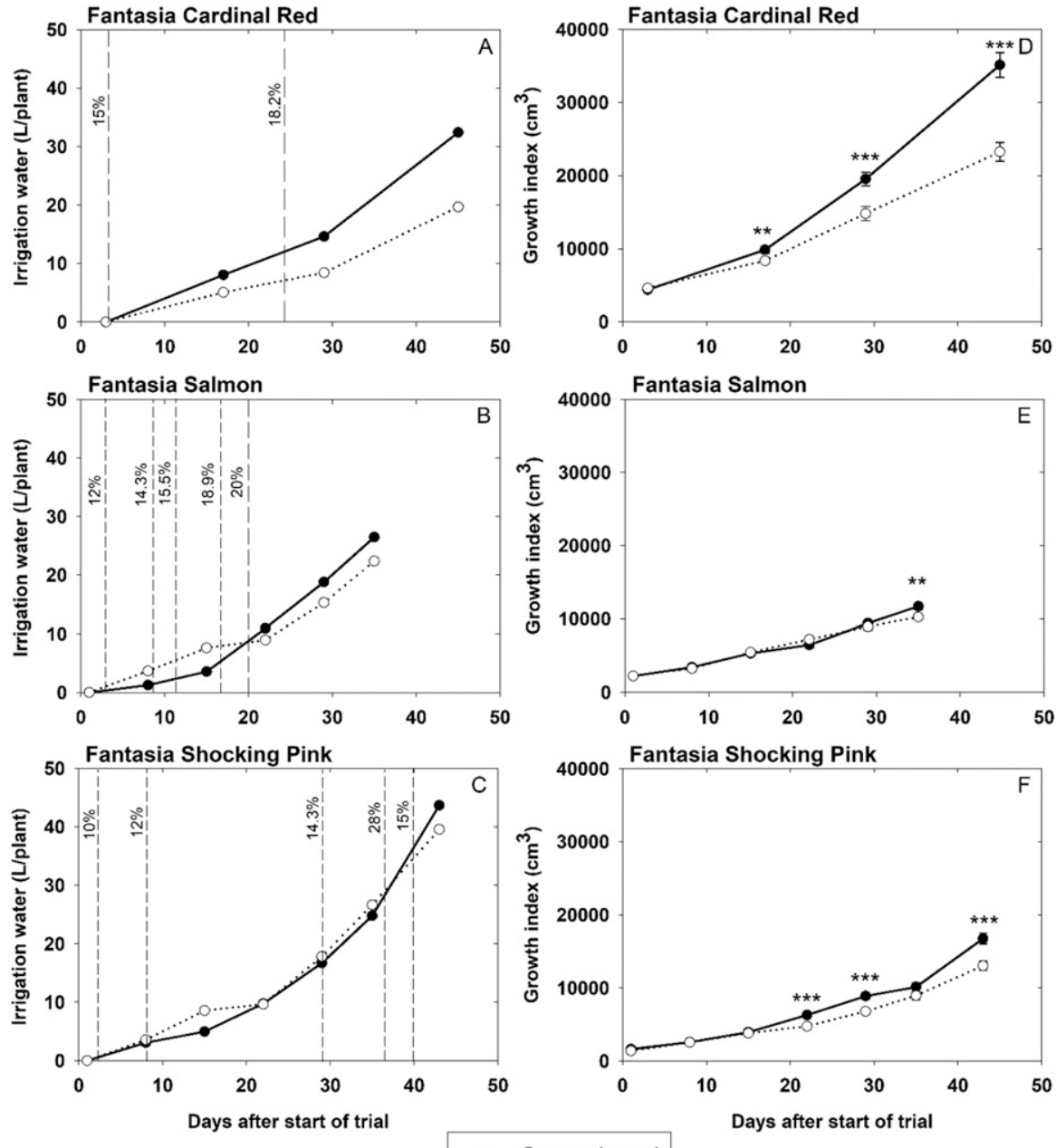

$\longrightarrow$ Sensor-based

Fig. 1. Comparative total irrigation water use (A-C) and growth indexes (D-F) for three cultivars of geranium using a soil moisture sensor-based automated irrigation system (sensor-based) or traditional timer-based irrigation (grower). Cultivars Fantasia Cardinal Red and Fantasia Shocking Pink were grown over 42-d periods, whereas Fantasia Salmon was produced over a 34-d period. Dotted vertical lines represent irrigation set points established by the grower, which correspond to soil moisture readings (set points only increased during the study). When readings fell below the established set point, an irrigation event lasting $300 \mathrm{~s}$ was triggered by the controlling computer system for the sensor-based irrigation system. Water usage (A-C) was assessed by direct comparison only, as a single flow meter was used for each treatment. Growth indexes

(growth index $=$ height $\times$ width $1 \times$ width 2 ) were calculated finding the product of the height of the canopy from the soil line, width of the canopy at its widest point, and the width $90^{\circ}$ from that point; ${ }^{* *}{ }^{*} P<0.001,{ }^{* *} P<0.01 ; 1 \mathrm{~L}=0.2642$ gal, $1 \mathrm{~cm}^{3}=0.0610$ inch $^{3}$. two-way repeated measures multivariate ANOVA (MANOVA) over the course of the trials. Experimental setup for irrigation of the 2014 poinsettia trial and 2015 geranium trials as well as labor calculations for the 2015 poinsettia trial were such that single flow meters and timers were used to track water use and labor allocation in each treatment. Because of this limitation, analysis was limited to direct comparisons. In 2015, expansion of poinsettia trials allowed installation of additional flow meters and replication of water use data that were examined using MANOVA analysis.

\section{Results}

Geranium. In three trials conducted with geraniums in Spring 2015 , direct comparisons of irrigation volume (liters of water applied to a crop), as well as statistical differences in growth indexes, were greater in sensor-based automated irrigation compared with timer-controlled irrigation (Fig. 1). In the first trial of 2015, a 'Fantasia Cardinal Red' crop was produced from week 6 to week 12 of the calendar year. In this trial, the greatest differences in irrigation volume applied and growth index were observed $(P<0.01)$. By the end of the first trial, the sensor-based automated irrigation treatment had used an additional $1010 \mathrm{~L}$ of irrigation water, or 12.74 L per plant (Fig. 1A). Growth indexes at the market-ready stage averaged $51 \%$ larger or $35,134 \pm 1701 \mathrm{~cm}^{3}$ in the sensor-based automated irrigation treatment, compared with 23,253 $\pm 1281 \mathrm{~cm}^{3}$ in timer-controlled treatment (Fig. 1D-F). Flowering was also reduced as a result of irrigating with sensor-based automated irrigation $(P=$ 0.02 ), with $0.9 \pm 0.2$ inflorescences per pot produced with the sensor-based automated irrigation system and $1.7 \pm$ 0.3 inflorescences per pot in timercontrolled treatment (Fig. 2).

Based on results from the first geranium crop ('Fantasia Cardinal Red'), the grower reduced the initial $\theta$ set point for the sensor-based automated irrigation system in subsequent crops (Fig. $1 \mathrm{~B}$ and C) to $10 \%$ $\theta$ ('Fantasia Shocking Pink') and 12\% $\theta$ ('Fantasia Salmon'). Despite the lowered initial $\theta$ set point, the grower continued to increase $\theta$ set points over the course of production. In direct comparison with timercontrolled irrigation, an additional 


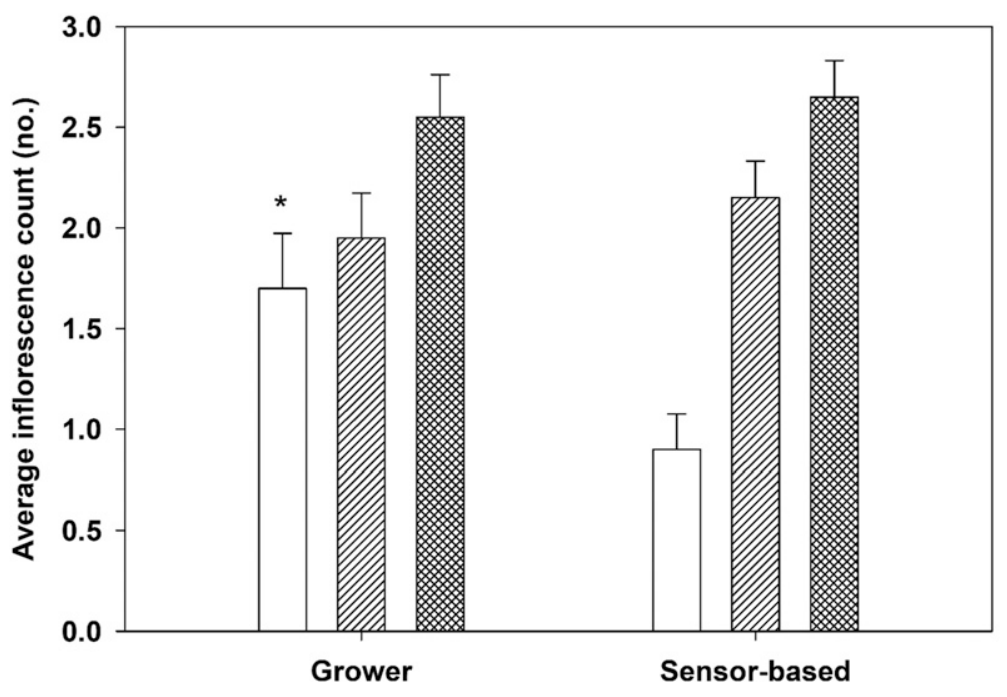

Treatment

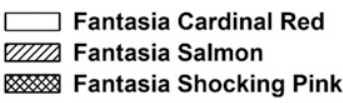

Fig. 2. Average number of inflorescences per pot for three geranium cultivars grown with a soil moisture sensor-based automated irrigation system (sensorbased), as compared with timer-based irrigation (grower). Cultivars Fantasia Cardinal Red and Fantasia Shocking Pink were grown over 42-d periods, whereas 'Fantasia Salmon' was produced over a 34 -d period; * $P<0.05$.

$325 \mathrm{~L}$ of total irrigation water, or $4.10 \mathrm{~L}$ per plant, was used by the sensor-based automated irrigation system to produce the cultivar Fantasia Salmon, whereas an additional $327 \mathrm{~L}$, or $4.12 \mathrm{~L}$ per plant, was used to produce the cultivar Fantasia Shocking Pink. In cultivar Fantasia Salmon (week 15 to week 20), the sensor-based irrigation system produced plants with a 14\% larger $(P<0.01)$ growth index, averaging $11,687 \pm 404 \mathrm{~cm}^{3}$ at market ready compared with timer-controlled plants that averaged $10,245 \pm 313$ $\mathrm{cm}^{3}$. Growth indexes from plants grown with sensor-based automated irrigation were $28 \%$ larger $(P<0.01)$ when market ready in 'Fantasia Shocking Pink' (week 15 to week 21), averaging $16,747 \pm 745 \mathrm{~cm}^{3}$, whereas timer-controlled plants averaged $13,048 \pm 634 \mathrm{~cm}^{3}$. Flower counts were equivalent between the two irrigation treatments in both 'Fantasia Salmon' $(P=0.49)$ and 'Fantasia Shocking Pink' $(P=0.72)$ (Fig. 2).

Poinsettia. Poinsettia production was trialed in both 2014 and 2015, with 'Prestige Red' used in both years and 'Christmas Day Red' only in 2015. In 2014, the sensor-based automated irrigation system used $0.54 \mathrm{~L}$ per plant of additional irrigation water per plant, or $163 \mathrm{~L}$ total for the block of 300 plants, when compared directly with timer-controlled irrigation. In 2015, the trial size and number of flow meters was expanded to allow for statistical analysis of water usage between the two irrigation treatments. The sensor-based automated irrigation system did not differ in its water use on a per-plant basis (11.75 \pm $1.30 \mathrm{~L})$ when compared with timercontrolled treatments $(13.52 \pm 1.02 \mathrm{~L})$ (Fig. 3). Per-plant water use was $\approx 12 \mathrm{~L}$ per plant under drip-line irrigation, which is similar to numbers reported by Morvant et al. (1998) and estimates derived from data published by Schuch et al. (1996). In both 2014 $(P=0.74)$ and $2015(P=0.79)$, 'Prestige Red' poinsettia received equivalent plant-quality ratings when comparing irrigation control by the sensor-based system and via timers. Plant-quality ratings also were equivalent in 'Christmas Day Red' poinsettia produced in $2015(P=0.34)$. Similarity of plant-quality ratings was confirmed by bract anthocyanin content measurements that were also similar across all three cultivar and year combinations (data not shown). Growth indexes were similar for
'Prestige Red' in $2014(P=0.16)$ and 'Christmas Day Red' in 2015 ( $P=$ 0.53 ) (Fig. 4); however, in 2015, 'Prestige Red' plants grown with the sensor-based automated irrigation system had a lower growth index $(P>0.01)$ than timer-irrigated plants. At sale, 2015 'Prestige Red' plants grown with the sensor-based automated irrigation system had a growth index of $48.8 \pm 0.6 \mathrm{~cm}$, whereas grower-irrigated plants averaged $52.3 \pm 0.7 \mathrm{~cm}$. The difference in growth index was also reflected in dry weight measurements and bract size (data not shown).

In 2015 , labor time devoted to irrigation activities was measured over three, 2 -week intervals. Between 8 and 24 Sept. 2015, $\approx 100 \mathrm{~min}$ of labor were devoted to timer-based irrigation treatments, whereas none was needed to manage the sensorbased automated irrigation treatments. Between 20 Oct. and 8 Nov. $2015, \approx 22 \mathrm{~min}$ of labor was devoted to timer-based irrigation treatments and 1 min was needed to manage sensor-based automated irrigation treatments. Between 3 and 8 Nov. $2015, \approx 45 \mathrm{~min}$ of labor was devoted to timer-based irrigation treatments, and no time was needed to manage the sensor-based automated irrigation treatments. Over the combined 6-week period, growers documented $\approx 166$ min of labor managing growercontrolled irrigation, compared with $\approx 1 \mathrm{~min}$ to monitor the sensor-based automated irrigation system. This equates to a roughly $99.5 \%$ reduction in labor requirements when using sensor-based automated irrigation.

\section{Discussion}

WATER USE AND PLANT GROWTH. Increased water use by the sensorbased automated irrigation system was observed in trials conducted with geraniums and the 2014 poinsettia trial. Equivalent water use was observed in the 2015 poinsettia trial. We hypothesize these results stem from the approach that DFC staff took to manage irrigation. Initial selection of irrigation set points and subsequent adjustment throughout crop development maintained high substrate moisture levels, in some cases close to saturation. For example, in the 'Fantasia Salmon' and 'Fantasia Shocking Pink' geranium crops, irrigation set points were increased four times over 


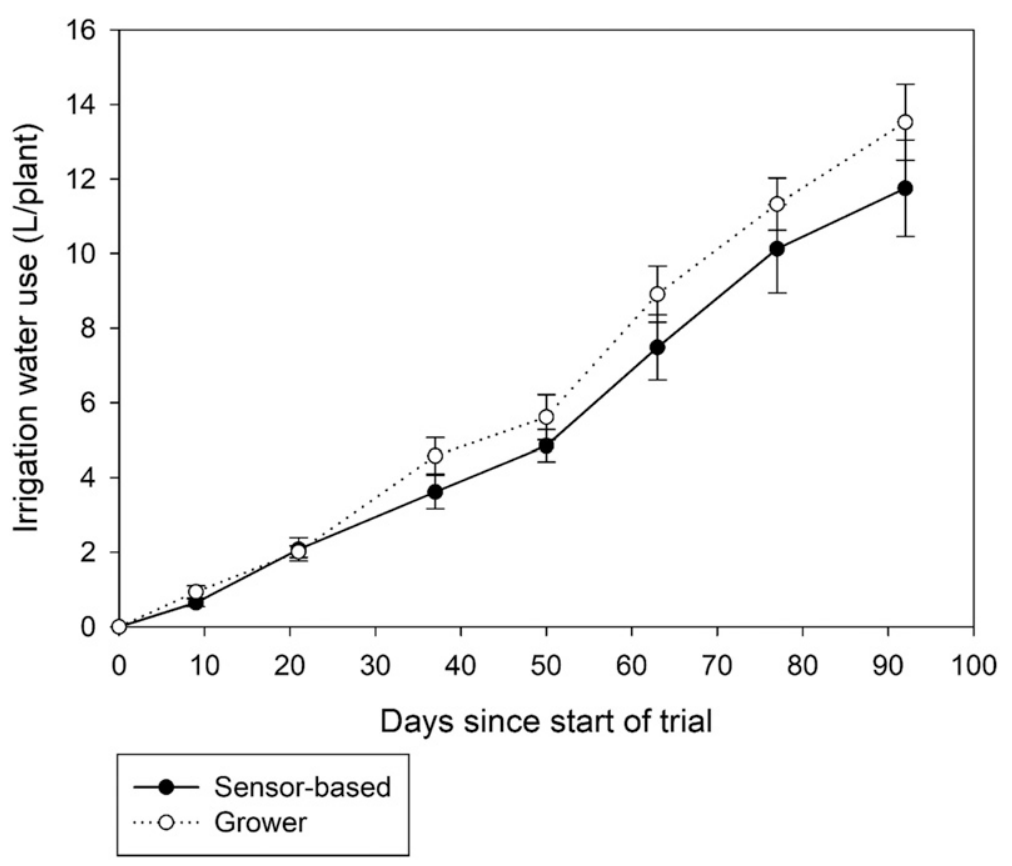

Fig. 3. Average cumulative irrigation water usage per plant in the production of poinsettia cultivars Prestige Red and Christmas Day Red by a soil moisture sensorbased automated irrigation system (sensor-based) and timer-based irrigation (grower). No statistically significant differences were noted during the course of the trial; $1 \mathrm{~L}=0.2642$ gal.

the course of the growth cycle, representing an $8 \%$ and $5 \%$ increase in $\theta$, respectively (Fig. 1A-C). Interviews with DFC personnel suggest that threshold management practices were the consequence of a combination of historical grower production preferences and a lack of awareness of how the sensor-based automated irrigation system operated, despite a 6-week initial training of DFC staff on system operation. Historical preferences for production were to maintain high levels of substrate moisture to act as a buffer against drought stress and to push crop growth. Grower perceptions of the sensor-based automated irrigation system were such that they believed irrigation set points needed to be gradually increased to match plant growth, as is recommended when using timer-based irrigation methods (Chappell et al., 2013b). In timerbased systems, the only method of applying more irrigation is to increase the run-time. The same behavior is not necessary when setting soil moisture sensor-based automated irrigation, because increased crop water use will automatically increase irrigation frequency. This perception resulted in the continual upward adjustment of irrigation set points by the section grower throughout crop production in all trials (Fig. 1A-C). Nemali and van Iersel (2006) demonstrated that a similar soil moisture-based irrigation system was able to maintain irrigation control as plants developed and their water usage changed, without modification of irrigation set points. In previous studies using sensor-based automated irrigation systems, researchers controlled irrigation set points that were established based on best management practices (Chappell et al., 2013b), substrate physical properties, and grower input. Once irrigation set points were established, they would remain in place by researchers for the duration of the production cycle (Alem et al., 2015b; Kim et al., 2011; van Iersel et al., 2010). High irrigation set points observed in this study may have contributed to results observed in the first geranium trial that exhibited increased growth indexes and reduced flowering, indicative of increased vegetative growth, which were observed in the crop irrigated with the sensor-based automated system. Increasing $\theta$ has been correlated with increased dry shoot weight and a reduction in flowers when combined with high fertility in petunias (Alem et al., 2015b; Kim et al., 2011; van Iersel et al., 2010). Despite reductions in flowering in 'Fantasia Cardinal Red'

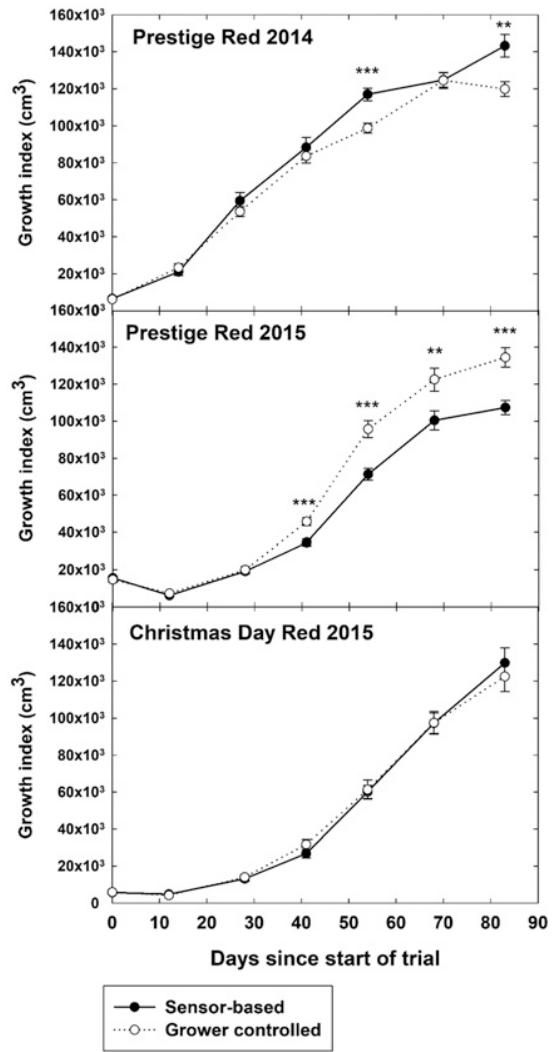

Fig. 4. Average growth indexes of poinsettia cultivars Prestige Red and Christmas Day Red in 2014 and 2015 grown with a soil moisture sensorbased automated irrigation system (sensor-based) and timer-based irrigation (grower). Growth indexes (growth index $=$ height $\times$ width $1 \times$ width2) are the product of the height of the canopy from the soil line, width of the canopy at its widest point, and the width $90^{\circ}$ from that point; ${ }^{*}{ }^{*} P<0.001,{ }^{*}{ }^{*} P<0.01 ; 1 \mathrm{~cm}^{3}=$ 0.0610 inch $^{3}$.

and increased water use and growth indexes in all geranium cultivars, marketability of crops grown with sensorbased automated irrigation system were not affected and plants were sold alongside those produced with grower-managed irrigation. Similarly, poinsettias produced in 2014 and 2015 by the sensor-based automated system had similar water usage as timer-irrigated plants, and were pulled for sale at the same time as timerirrigated plants. Differences in the growth index between sensor-based and timer-based irrigation in the 2015 'Prestige Red' crop were not judged to impact marketability. Precise control of soil moisture contents afforded by the sensor-based automated system allows for selection of 
irrigation set points so that mild drought stress could be imposed throughout crop development. In this study, DFC staff established irrigation set points based on intuition and experience with the crop, and were not inclined to use drought stress to regulate plant size because of fears of underwatering and negatively affecting bract size and color quality. In the initial consultation period with DFC owners, head grower, and section grower, researchers explained the mechanisms of control of the sensorbased automated system and how low irrigation set points could be used for water savings and height control. However, gradual increases in the irrigation set points throughout the crop cycle continued throughout all trials conducted at DFC. This is an important difference with how the system was designed and had been historically used by researchers. This points to the need for a continuing education and/or consulting component to sensor-based automated irrigation setup and operation. Similar problems are common in technology adoption across agriculture, whereby historical grower behaviors do not change as technology changes, and therefore growers require continual education to not only ensure adoption, but also proper use to maximize efficiencies and return on investment (Long et al., 2016). Some steps have been taken to provide grower-based knowledge on soil moisture sensorbased irrigation systems through the USDA Specialty Crops Research Initiative-funded Smart Farms project (USDA, 2015b). However, these self-guided learning modules were available to DFC staff, and at no time did the staff access these modules to increase knowledge of the sensorbased automated system. This points to a need for face-to-face consulting activities, beyond that of an initial consultation/training period, to maximize the value of precision irrigation technology. This is supported by economic and social science studies that have highlighted the importance of continued technical support from either extension agents or social networks to facilitate adoption of new agricultural technology (Genius et al., 2013; Maertens and Barrett, 2013). This was confirmed by DFC owners, who indicated that integrating fully the sensor-based automated system into their entire irrigation system would be considered if technical support could be provided after termination of this project.

One grower concern about sensor-controlled irrigation was that it would not be practical to measure $\theta$ in all pots, making it difficult to account for spatial variability caused by microclimates, particularly from pad side to fan side of the greenhouse. Henderson et al. (2018) showed that such microclimates do indeed exist within greenhouses, and that these microclimates result with different evapotranspiration rates as well as $\theta$ s within a crop. Interestingly, Henderson et al. (2018) also found that this spatial variability did not result in variability in plant growth. DFC staff, when presented with these findings, concluded that soil moisture sensor-based irrigation would be suitable for their commercial greenhouse operation.

Technology adoption And LABOR CONSIDERATIONS. At the request of DFC owners, greater implementation of the system occurred over the 2-year study. In 2014, the sensor-based automated system controlled irrigation to 300 poinsettias, and in 2015 this had increased to 1800 plants. This same trend was seen in geraniums, with the initial trial controlling irrigation for 300 plants and later trials controlling irrigation for 900 plants. This greater reliance on sensor-based automated irrigation to control irrigation was seen as strong evidence of acceptance of the technology. This method of initial apprehension followed by gradual acceptance of new technology was attributed, by DFC staff, to greater trust in the reliability of the technology, as well as the responsiveness and troubleshooting abilities of researchers overseeing the study. This method of technology acceptance followed the theory of social capital in adoption decisions outlined by Hunecke et al. (2017). In this theory, technology adaptation is maximized when the technology is backed by a reputable institution, is deemed reliable and trustworthy, and improves profits or increases efficiency. In addition, DFC owners indicated that cost of the sensor-based automated irrigation system would not preclude adoption, with an installed system cost of $\$ 4500$. Cost is a critical barrier to adoption of technology in agriculture (Long et al., 2016), and this lack of apprehension related to cost is a positive sign for future adoption. Although the adoption of the technology was not in the manner hypothesized, to reduce water usage, growers still found utility in the system.

In interviews with the owners of DFC, they conveyed that the real value of the sensor-based automated irrigation system was the ability to allow for labor reallocation away from irrigation management during peak production and shipping periods. The freedom to reallocate labor was valued as an opportunity cost, which is difficult to value, yet of vital importance to business success (Quah and Haldane, 2007). Water usage, although a consideration, was not a management priority because of the relatively low cost of water and high availability of water in the region. Water pricing is a driving force of irrigation technology adoption globally, with low adoption rates of precision irrigation technology directly tied to low water cost and high levels of supply (Giannakis et al., 2016). Moreover, DFC used a number of efficient irrigation practices before this study, producing crops under low-flow drip lines in combination with trained staff to minimize leaching via visual observation and monitoring during an irrigation cycle. The owner commented that section growers were often overwhelmed during peak production, and dry growing practices that were historically observed were more often the result of neglect than good horticultural practice. The sensor-based system provided a mechanism to automate irrigation, a task normally requiring frequent grower input and observation, allowing growers to focus on other production tasks.

Given the high grower-communicated opportunity cost of the technology, monetary savings due to labor savings were postulated to be high. Raw data of labor use were collected for three, 2-week periods during the 2015 poinsettia production cycle. Over the combined 6-week period, grower-controlled irrigation treatments required $\approx 166 \mathrm{~min}$ of labor compared with $1 \mathrm{~min}$ of labor for the sensor-based system. This equates to a $99.5 \%$ reduction in 
irrigation-related labor requirements when relying on sensor-based automated irrigation, or $60 \mathrm{~h} 52 \mathrm{~min}$ per poinsettia crop rotation extrapolated over the entire DFC growing operation. Assuming a $\$ 15$ per hour wage, this would equal $\approx \$ 900$ in labor savings per poinsettia crop cycle. Extrapolating this to three major crop cycles (one poinsettia and two geranium) that occur over the course of the year at DFC, estimates of labor savings using a sensor-based automated irrigation system would total $\approx \$ 2700$ per year. This would mean a payback period of roughly a little more than 1.5 years for the sensorbased irrigation system. When asked if the time savings would lead to a reallocation of tasks or a reduction in labor force, DFC owners indicated that all time savings would lead to reallocation of tasks and no labor force reduction. Specifically, labor savings would allow employees to focus on pulling and shipping orders as well as scouting crops for abiotic and biotic stress. Posadas et al. (2008) reported a similar result when looking at increased automation in horticultural production practices, finding that automation did not lead to a reduction in labor force but instead more efficient allocation of that labor.

\section{Conclusions}

We observed how automated precision irrigation technology was used by a floriculture grower when, after a brief training period, the grower was allowed to use the system as the grower saw fit over a 2 -year period. The sensor-based automated irrigation system was able to produce plants of equal quality and value to the grower's historical (timer-based) irrigation practices, with no marketable differences in plant size over 2 years and five cultivars of two species. Despite the surprising absence of reductions in water usage, which have been observed in previous studies in which precision irrigation was used, adoption and expansion in use of this emerging technology by the grower took place because of its utility as a labor-saving technology. Reduced labor hours associated with irrigation management allowed for reallocation of that labor toward other production and shipping-related activities, which was especially important during peak production periods when labor was at a premium. It also became apparent that continued technical support would have helped the DFC staff use the technology to its full potential. This research points to the need for intensive on-farm studies to better document and understand the relationship between automated precision irrigation systems and labor savings and reallocation in floriculture production.

\section{Literature cited}

Alem, P., P.A. Thomas, and M.W. van Iersel. 2015a. Controlled water deficit as an alternative to plant growth retardants for regulation of poinsettia stem elongation. HortScience 50:565-569.

Alem, P., P.A. Thomas, and M.W. van Iersel. 2015b. Substrate water content and fertilizer rate affect growth and flowering of potted petunia. HortScience 50:582-589.

Belayneh, B., J. Lea-Cox, and E. Lichtenberg. 2013. Costs and benefits of implementing sensor-controlled irrigation in a commercial pot-in-pot container nursery. HortTechnology 23:760-769.

Bellenger, M., D. Fields, K. Tilt, and D. Hite. 2008. Producer preferences for migrant labor and the wage, hours, and gross sales effects in Alabama's horticulture industry. HortTechnology 18:301-307.

Bureau of Labor Statistics. 2015. Occupational outlook handbook, 2013-14 Edition: Agricultural workers. 21 Apr. 2017. <http://www.bls.gov/ooh/farmingfishing-and-forestry/agricultural-workers. htm>.

Chappell, M., M. van Iersel, E. Lichtenberg, J. Majstrik, P.A. Thomas, J. Ruter, and S. Wells. 2012. Benefits of precision irrigation of Gardenia augusta 'Heaven Scent': Reducing shrinkage, shortening the cropping cycle and economic impact. Proc. Southern Nursery Assn. Res. Conf. 57:321-323.

Chappell, M., S.K. Dove, M.W. van Iersel, P.A. Thomas, and J. Ruter. 2013a. Implementation of wireless sensor networks for irrigation control in three container nurseries. HortTechnology 23:747-753.

Chappell, M., J. Owen, S. White, and J. Lea-Cox. 2013b. Irrigation management practices. In: T. Yeager, T. Bilderback, D. Fare, C. Gilliam, J. Lea-Cox, A. Niemiera, J. Ruter, K. Tilt, S. Warren, T. Whitwell, and R. Wright (eds.). Best management practices: Guide for producing nursery crops. 3rd ed. 19 Sept. 2013. <http:// contents.sna.org/bmpirrigation.html>.
Costanza, R., R. de Groot, P. Sutton, S. van der Ploeg, S.J. Anderson, I. Kubiszewski, S. Farber, and R.K. Turner. 2014. Changes in the global value of ecosystem services. Glob. Environ. Change 26:152-158.

Fereres, E., D.A. Goldhamer, and L.R. Parsons. 2003. Irrigation water management of horticultural crops. HortScience 38:1036-1042.

Fulcher, A., A.V. LeBude, J.S. Owen, S.A. White, and R.C. Beeson. 2016. The next ten years: Strategic vision of water resources for nursery producers. HortTechnology 26:121-132.

Genius, M., P. Koundouri, C. Nauges, and V. Tzouvelekas. 2013. Information transmission in irrigation technology adoption and diffusion: Social learning, extension services, and spatial effects. Amer. J. Agr. Econ. 96:328-344.

Giannakis, E., A. Bruggeman, H. Djuma, J. Kozyra, and J. Hammer. 2016. Water pricing and irrigation across Europe: Opportunities and constraints for adopting irrigation scheduling decision support systems. Water Sci. Technol. Water Supply 16:245-252.

Henderson, S., D. Gholami, and Y. Zheng. 2018. Soil moisture sensor-based systems are suitable for monitoring and controlling irrigation of greenhouse crops. HortScience 53:552-559.

Hunecke, C., A. Engler, R. Jara-Rojas, and P.M. Poortvliet. 2017. Understanding the role of social capital in adoption decisions: An application to irrigation technology. Agr. Syst. 153:221-231.

Kim, J., M. Chappell, M.W. van Iersel, and J. Lea-Cox. 2014. Wireless sensor networks for optimization of irrigation, production, and profit in ornamental production. Acta Hort. 1037:643-650.

Kim, J. and M.W. van Iersel. 2011. Slowly developing drought stress increases photosynthetic acclimation of Catharanthus roseus. Physiol. Plant. 143:166-177.

Kim, J., M.W. van Iersel, and S.E. Burnett. 2011. Estimating daily water use of two petunia cultivars based on plant and environmental factors. HortScience 46:12871293.

Kohanbash, D., G. Kantor, T. Martin, and L. Crawford. 2013. Wireless sensor network design for monitoring and irrigation control: User-centric hardware and software development. HortTechnology 23:725-734.

Lea-Cox, J.D., J. Williams, and M.A. Mellano. 2018. Optimizing a sensorbased irrigation protocol for a large-scale 
cut-flower operation in southern California. Acta Hort. 1197:219-225.

Lea-Cox, J.D., W.L. Bauerle, M.W. van Iersel, G. Kantor, T.L. Bauerle, E. Lichtenberg, D.M. King, and L. Crawford. 2013. Advancing wireless sensor networks for irrigation management of ornamental crops: An overview. HortTechnology 23:717-724.

Lichtenberg, E., J. Majsztrik, and M. Saavoss. 2013. Profitability of sensorbased irrigation in greenhouse and nursery crops. HortTechnology 23:770-774.

Ling, P.P. 1994. From mechanization to the information highway. Greenhouse systems: Automation, culture and environment. Proc. Greenhouse Systems Intl. Conf. 1994:5-7.

Long, T.B., V. Blok, and I. Coninx. 2016. Barriers to the adoption and diffusion of technological innovations for climatesmart agriculture in Europe: Evidence from the Netherlands, France, Switzerland, and Italy. J. Clean. Prod. 112:9-21.

Maertens, A. and C.B. Barrett. 2013. Measuring social networks' effects on agricultural technology adoption. Amer. J. Agr. Econ. 95:353-359.

Majsztrik, J.C., E.W. Price, and D.M. King. 2013. Environmental benefits of wireless sensor-based irrigation networks: Case-study projections and potential adoption rates. HortTechnology 23:783793.

Mathers, H.M., A.A. Acuña, D.R. Long, B.K. Behe, A.W. Hodges, J.J. Haydu, U. K. Schuch, S.S. Barton, J.H. Dennis, B.
K. Maynard, C.R. Hall, R. McNeil, and T. Archer. 2010. Nursery worker turnover and language proficiency. HortScience 45:71-77.

Morvant, J.K., J.M. Dole, and J.C. Cole. 1998. Irrigation frequency and system affect poinsettia growth, water use, and runoff. HortScience 33:42-46.

Nemali, K.S. and M.W. van Iersel. 2006. An automated system for controlling drought stress and irrigation in potted plants. Scientia Hort. 110:292-297.

Posadas, B.C., P.R. Knight, R.Y. Coker, C.H. Coker, S.A. Langlois, and G. Fain. 2008. Socioeconomic impact of automation on horticulture production firms in the northern Gulf of Mexico region. HortTechnology 18:697-704.

Quah, E. and J.B.S. Haldane. 2007. Costbenefit analysis. 5th ed. Routledge, New York, NY.

Ristvey, A.G., B.E. Belayneh, J.D. Lea-Cox, and J. Iferd. 2018. Automated sensor-control strategies for drip irrigation of containerized chrysanthemum. Acta Hort. 1197:211-218.

Saavoss, M., J. Majsztrik, B. Belayneh, J. Lea-Cox, and E. Lichtenberg. 2016. Yield, quality and profitability of sensorcontrolled irrigation: A case study of snapdragon (Antirrbinum majus L.) production. Irr. Sci. 34:409-420.

Schuch, U., R.A. Redak, and J. Bethke. 1996. Whole-plant response of six poin- settia cultivars to three fertilizer and two irrigation regimes. J. Amer. Soc. Hort. Sci. 121:69-76.

Strzepek, K. and B. Boehlert. 2010. Competition for water for the food system. Philosophical Trans. Royal Soc. B 365:2927-2940.

U.S. Census Bureau. 2015. Income and poverty in the United States: 2014. 28 Apr. 2016 . <http://www.census.gov/ content / dam / Census / library / publications $/ 2015 / \mathrm{demo} / \mathrm{p} 60-252$.pdf $>$.

U.S. Department of Agriculture. 2015a. Floriculture crops-2014 Summary. 6 Apr. 2016 . <http://usda.mannlib. cornell.edu/usda/current/FlorCrop/ FlorCrop-06-04-2015.pdf>.

U.S. Department of Agriculture. 2015b. SCRI-MINDS: Smart Farms Knowledge Center. 21 Apr. 2017. <http://www. smart-farms.org/>.

van Iersel, M.W., R.M. Seymour, M. Chappell, and S. Dove. 2009. Soil moisture sensor-based irrigation reduces water use and nutrient leaching in a commercial nursery. Proc. Southern Nursery Assn. 54:17-21.

van Iersel, M.W., S. Dove, J.-G. Kang, and S.E. Burnett. 2010. Growth and water use of petunia as affected by substrate water content and daily light integral. HortScience 45:277-282. 